\title{
ABORIGINES AND EUROPEAN SOCIAL HIERARCHY
}

\author{
Henry Reynolds
}

Until the 1840s the main emphasis of policy makers in the Australian colonies was on the incorporation of the Aborigines into colonial society. Confidence in this plan declined as the century progressed and some argued all along that the blacks belonged to a doomed race which could never be assimilated. Whereas assimilationists of the mid-twentieth century made no mention of class when they projected future Aboriginal adoption of the 'Australian way of life' their counterparts a hundred years and more earlier usually had a clear picture of a hierarchical society of ranks and orders differentiated by wealth and power and status. Views about colonial society varied and changed over time yet any discussion about the absorption of the Aborigines necessarily involved the question of where in the hierarchy they would be placed. The race question was by its very nature also a class question. This was apparent in almost every area of white-Aboriginal relations - in the policies and attitudes of the Europeans and in the Aboriginal response as well.

The common view amongst officials, missionaries and well-to-do settlers was that the Aborigines would become landless labourers. Governor Macquarie saw them becoming useful 'as labourers in agricultural employ or among the lower class of mechanics'. ${ }^{1}$ A generation later Governor Gipps considered means by which they could be induced to become 'voluntary labourers for wages'. It was, he argued, 'by the employment of the Aborigines as labourers for wages ... that I consider the civilization of the Aborigines . . must be worked out'. ${ }^{2}$ In the Port Phillip district, Aboriginal Protector William Thomas remarked that 'the highest pitch the Aborigines could ever arrive to would be that of a hired labourer'. ${ }^{3}$ Civilisation meant the inculcation of those qualities considered desirable in the lower orders. Civilisation meant proletarianisation.

The question of civilisation, Governor Hutt argued, 'could only be answered by discovering some method of overcoming this repugnance to regular work'. ${ }^{4}$ Charles Symmons, the Western Australian Protector of Aborigines, thought that 'one of the best means of ameliorating the condition of the native population, and gradually raising them in the scale of civilization was to encourage them in a desire for steady employment'.5 But how was change to be effected, how could the 'capricious

Henry Reynolds teaches history at James Cook University and is the author of The Other Side of the Frontier (Townsville 1981 and Ringwood 1982). He is now working on aspects of frontier society, with emphasis on European responses to the Aborigines.

1 Macquarie to Bathurst, 8 October 1814, HRA 1/8/368.

2 Aborigines: Australian Colonies, BPP 34/627/1844/105-6.

${ }^{3}$ Thomas, 18 September 1841 , ML MSS 214/8.

4 Hutt to Stanley, 8 April 1842, Aborigines: Australian Colonies, BPP 34/627/1844/412.

${ }^{5}$ Symmons to Colonial Secretary, 18 September 1848 , WA CSO/1848/173/36. 
hunter' be turned into the 'steady labourer'?6 The colonists found the task infinitely frustrating. Aborigines strongly resisted the demands of regular labour as a chorus of European complaints attested. 'They appear generally to feel they owe us nothing', Port Phillip Protector E.S. Parker wrote, and that they are 'under no obligation to work'. ${ }^{7}$ His colleague, William Thomas, remarked that the blacks he knew would 'only work a couple of days and then rest' telling him that 'this is what they do in the bush and how it has always been'. Their prevailing character as labourers, he lamented, was indolence. They preferred 'sleep and saunter to work'. ${ }^{8}$

Many plans were proposed to discipline refractory blacks. 'Though by nature wild', wrote Governor Gipps, and with difficulty induced to submit 'to the restraints which are imposed on ordinary labourers abundant proof exists that they may be made to do so'.9 Archdeacon Scott suggested a more subtle approach, hoping that blacks would learn the 'nature of labour' by feeling the 'benefits of enjoying and living on the produce', 10 by learning to appreciate the 'sweets of property' as Charles Griffith, a Victorian magistrate put it. ${ }^{11}$ William Thomas decided to give flour to those who had worked, denying it to others in order to inculcate the link between working and eating. This annoyed the Aborigines. They came back the next day threatening to return to the mountains and live 'like before white man came' when people took it in turns to hunt and 'didn't have to work everyday'.12 'They do not court a life of labour', a perceptive settler remarked,

that of our shepherds and hut-keepers - our splitters or bullock drivers - appears to them one of unmeaning toil, and they would by no means consent to exchange their free unhoused condition for the monotonous drudgery of such a dreary existence. ${ }^{13}$

Missionaries were deeply interested in the encouragement of a work ethic amongst Aborigines. Members of the New South Wales Society for Promoting Christian Knowledge Among the Aborigines wanted to lead the blacks to an acquaintance with the first principles of religion but also believed that,

as an important and indispensable Duty, it is incumbent on us, by every pious and conciliatory means to recommend to the Aborigines of New South Wales the habits of useful industry. ${ }^{14}$

On the stations of the Port Phillip Protectorate every endeavour was made to 'induce the natives to habits of industry'15 while the missionary Joseph Orton urged

${ }^{6}$ Collie, Select Committee on Aborigines, BPP 7/538/1837/129.

7 Parker, Papers of the Port Phillip Protectorate, VPRO, Box 12.

8 Thomas, 18 September 1841, ML MSS 214/8.

9 Gipps to Legislative Council, 8 June 1841, Aborigines: Australian Colonies, BPP $34 / 627 / 1844 / 119$.

10 Scott to Darling, 1 August 1827, Woolmington, 1973:186.

11 Select Committee on the Aborigines and the Protectorate, NSWLCV \& P 1849/17.

12 Thomas, 18 November 1840 , ML MSS 214/8.

13 Select Committee on the Aborigines and the Protectorate, NSWLCV \& P 1849/17.

14 Bonwick, 12 August 1819, ML Box 50.

15 Annual Report of Chief Protector, 1841, Papers of the Port Phillip Protectorate, VPRO, Box 10. 
'assiduous, unremitting efforts to induce them to profitable industry'.16 Assistant Protector Parker concurred. 'They must', he wrote, 'be taught to estimate the value of labour and the beneficial results of industry'.17 But the link between labour, religion and social control was most clearly enunciated by the Port Phillip missionary John Harper who wrote:

They must be taught the art of cultivation ... and it will only be by keeping them employed, that their minds will be made susceptible of Religious impressions . . . They must also be brought to settle upon a spot where they will always be under the inspection of their teachers. ${ }^{18}$

Aboriginal resistance to the discipline of regular labour paralleled the situation in many parts of the world where capitalism penetrated traditional peasant and huntergatherer societies. English workers themselves conducted a long struggle against the new patterns of life imposed by early industrialism. The parallels with the Australian situation were apparent to colonial officials, missionaries and employers. While the subjects differed the end in view was similar. The Aboriginal problem was seen in much the same light as the contemporaneous task of controlling the itinerants, paupers, slum dwellers, highland clansmen and squatters living on the shrinking commons at home in Britain. The institutions planned and established for Aborigines were based on those of the early industrial revolution - the ragged school, the poor house, the penitentiary.

William Thomas directly linked labour problems among Port Phillip blacks with those at home in England. One Monday morning in 1842 he wrote in his diary:

this morn scarce a Black would work. In fact I find generally that the Blacks are lazy on the Monday like English Cobblers. I fear they will keep St. Monday. ${ }^{19}$ His planned solution was to initiate the children into habits of industry at preparatory schools where "business should be carried on as at the Philanthropic School near London'.20 A few years earlier the New South Wales Colonial Secretary, Alexander Macleay, drew up instructions for an Aboriginal settlement at Port Phillip, the object of which was to induce them to offer their labour in return for food and clothing'. It was to be managed 'upon the System of Mr Owen's establishment at Lanark or under any similar arrangement'. ${ }^{21}$ At Poonindie the Anglican clergyman Matthew Hale consciously modelled his institution on the Ragged Schools in England. Blacks would be gathered together to be kept under regular Christian instruction, 'where the attempt may be made to lead them by degrees into habits of industry and a more settled mode of life'.22

16 Orton, 3 December 1840, ML MSS A1715.

17 Report on the Loddon Station, Papers of the Port Phillip Protectorate, VPRO, Box 12.

18 Harper, 23 April 1827, Bonwick ML Box 53.

19 Thomas, 1 February 1842, ML MSS 214/8.

20 Thomas to Robinson, 1 January 1840 , ML MSS 214/8; Thomas, 18 September 1841 , ML MSS $214 / 8$.

21 Macleay to Lonsdale, 9 December 1836, NSW \& Vic Misc. Papers, 1817-73, ML MSS A1493.

22 Hale, 1889:9. 


\section{ABORIGINES AND EUROPEAN SOCIAL HIERARCHY}

But it was not just habits of industry which had to be inculcated but also the obedience and deference required in the master-servant relationship. The problem was that the blacks 'did not understand exalted rank', and consequently it was 'difficult to get into a black fellow's head that one man is higher than another'. ${ }^{23}$ A West Australian settler referred to local blacks who did not 'know the restraint of being anything like the servant of another'. ${ }^{24}$ On the other side of the continent William Thomas referred to Aborigines who had been brought up among the whites as 'ones who have been taught to bow the knee'. ${ }^{25}$ His colleague E.S. Parker argued that blacks on the Protectorate stations would not be fitted for employment as hired servants until they had been taught 'to have some idea of the respective relations of the Master and Servant'.26 The missionary James Gunther noted that amongst the blacks he was familiar with

no man has an idea of serving another. This idea of their own dignity and importance is carried so far that they hesitate long before they apply the term $\mathrm{Mr}$. to any European even when they know full well the distinction we make between master and servant. ${ }^{27}$

Gunther related an incident which illustrated the conflict of values. He ordered a black living on the mission to plough a field. In reply the young man asked why he should, saying 'he was master too'. ${ }^{28}$ William Thomas noted a similar occurrence in his diary. A young Aborigine recruited into the Port Phillip Native Police retumed to the Protectorate station complaining of ill treatment. He concluded by saying that the white officer was 'no his master'. When taken before the local bench the magistrate told Thomas to give the lad a good scolding and impress on him 'that any Gentleman a Soldier was sent with was his master for the time being'.29

But Aborigines did work for Europeans in all parts of the country as guides, trackers, shepherds, stockmen and labourers. The compulsion either of hunger or of the gun barrel often played a part in the induction into the work force. But that was not the whole story. Reciprocity not fear was often the source of Aboriginal action. In a particularly perceptive comment the colonial historian G.W. Rusden wrote of black servants that 'affection made them willingly perform acts of service regarded as the fruits of friendship rather than as tasks of servants' ${ }^{30}$ The Quaker missionary G.W. Walker similarly observed that if the blacks 'do service for others, they do it through courtesy', ${ }^{31}$ while a New England pioneer remarked that local clans saw

\footnotetext{
23 Bulmer, 1888:30.

24 Collie, Select Committee on Aborigines, BPP 7/538/1837/129.

25 Thomas, 18 September 1841, ML MSS 214/8.

26 Parker, Papers of the Port Phillip Protectorate, VPRO, Box 12.

27 Gunther, ML MSS B505.

28 Gunther, ML MSS B504/256.

29 Thomas, 21 October 1843, ML MSS 214/8.

30 Rusden, 1883(IN):237.

31 Walker, 1902:249.
} 
work performed for her family 'as a personal favour, and gave us to understand as much'.32

European awareness of Aboriginal motivation probably varied widely. Some thought they had trained black servants into habits of deference and obedience. Others, more conscious of the true situation, exploited their status as de facto kin. Thus Robert Dawson the manager of the Australian Agricultural Company outlined his methods of dealing with local clans:

I took infinite pains to ingratiate myself with them upon all proper occasions. I danced and sang with them, and entered into all their sports and gambols as an applauding spectator; I accompanied them to their fights; gave them names to their children; conferred upon them offices and badges of distinction; and supplied them with muskets and ammunition, with which to pursue their sports. I gave them food in return for their services and a hearty welcome wherever and whenever I met them. In return for all this, I was treated as one belonging to them and almost necessary to them. I was known and talked of by them far and near, and designated as brother, from whom much had been received and much was still expected. Every person who knows anything of human nature, must be aware that man, in his wild state, is not to be conciliated, or tamed into respectfulness of demeanour and usefulness of conduct, by other than similar means to these. ${ }^{33}$ The situation which emerged in the more settled districts can be seen through the eyes of William Thomas who initially saw labour as the key to assimilation and 'civilization'. By the early 1850s he reported that the Port Phillip blacks were working in a whole range of rural occupations - mustering, horse-breaking, sheep washing, reaping, 'even tying up' and they did 'as fair a days work as a day labourer'. As 'hirelings working for their own support' they knew the value of money and received hard cash very little below the European standard'. Involvement in the economy had influenced Aboriginal behaviour but had not radically changed it. Casual work had created a pattern of movement very similar to the old ways but their "erratic movements' were now due to 'shifting from one locality to another as they finish their work'; so that while 'their nationality' was weakened it was 'not totally broken up' ${ }^{34}$

Aborigines had not been assimilated. They had compromised when necessary and the role of casual, itinerant labour allowed a degree of independence from the European economy especially when supported by vestigial hunting and gathering. William Thomas described a pattern of articulation which became common all over the continent. Despite the participation in the rural work force all efforts

. . . so far to improve their condition have been without avail. I have pressed, the farmers and others have urged they become as us not merely in work and diet but to stop in house ... comfortably clad and stretched . . . is what they'll hear nought of, the hook, axe or bridle down and all further civilization for the day is over, off goes apparel and they bask under the canopy of heaven as in their

32 McBryde, 1978:248.

33 Dawson, 1830:272-3.

34 Thomas, 17 January 1854 , ML MSS 214/8. 


\section{ABORIGINES AND EUROPEAN SOCIAL HIERARCHY}

primative [sic] wildness evidently enjoying their freedom from encumbrance ... nor have they any desire to be muddled with further, such is their wandering propensities, that all kindness, entreaty or persuasion cannot secure them one day beyond their determination and latterly they have been particularly cautious how they make bargains for labour on this account. ${ }^{35}$

Gipps believed that it was through contact with Europeans, 'by being placed as nearly as possible on a par with them,, ${ }^{36}$ that the 'civilization' of the Aborigines was most likely to be advanced. He did not mean on a par with all Europeans but only with the lower orders. Indeed numbers of the colonial elite frequently affirmed the similarity between the blacks and the white working class. Aborigines were 'but little inferior in intellect to the uneducated peasantry of Europe': ${ }^{37}$ they were, asserted the magistrates at Bungonia, in every respect 'as intelligent as the working people around us' ${ }^{38}$ The Surveyor-General Thomas Mitchell thought that in 'manners and general intelligence, they appear superior to any class of white rustics I have seen', ${ }^{39}$ while John Dixon, author of a book on Van Diemen's Land, thought that many colonists had 'poor pretensions to rank above' the blacks. ${ }^{40}$ The arch-conservative, G.W. Rusden, was even more emphatic. When comparing the blacks with 'only the lower and uneducated European' it would be hazardous to affirm that 'the black is inferior to the white' while in intelligence, good humour and loyalty the Aborigines 'often put to shame the boors among the vaunting Caucasian intruders' ${ }^{41}$

These remarks need some explanation given the emphasis in recent scholarship on the pervasiveness of white racism. But by equating Aborigines with the 'peasantry' the colonial elite was able at one and the same time to confirm its support for the orthodox Christian monogenesist view of race prevailing up to the 1850 s and to emphasise its own elevation above the white working class. In a society where the lower orders seemed to have forgotten their place the Aborigines were marked by racial characteristics for low status. They helped maintain the correct distance between the ranks and orders of society. While they retained identifiable racial characteristics they could not aspire to social equality. As a result familiarity between white master and black servant did not call into question the proper ordering of society. Thus the Port Phillip landowner Edward Curr made the illuminating comment that black servants were 'generally treated by the educated squatter with a familiarity which argued something of equality, and in which the labourer never shared'.42 A Maryborough magistrate H.B. Sheridan told a Queensland Select Committee that a

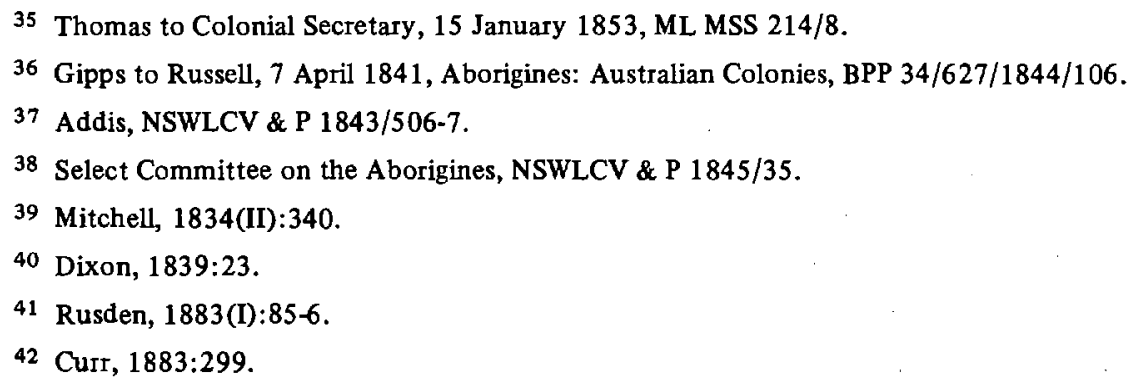


'gentleman gets on much better with the blacks than an ordinary man' because there was a 'natural good breeding in the black which co-incided with a similar quality in others' ${ }^{43}$ An old colonist Ebenezer Thorne thought the blacks had a dignity of gesture and gracefulness 'that we look for in vain among our labouring classes and that we usually connect with the idea of a gentleman'. 44

Not surprisingly white workers were unenthusiastic about being placed on a par with the Aborigines. Economic motives were important, Parker noting the 'aversion on the part of most European labourers to see the natives taught to work', avowedly for the reason that 'a successful result might interfere with the price of labour'.45 But it was not solely a question of wage rates and jobs. Status and self-esteem were also involved and beyond that class relations in society as a whole. Having commented on the familiarity that often existed between white masters and black servants, Edward Curr observed that the Aboriginal worker was 'a good deal bullied by the white labourer, who lost no opportunity of asserting his superiority over him'. ${ }^{46}$ The South Australian settler Richard Penny made a more detailed analysis of the situation. All efforts for civilising the natives, he wrote in 1842 , had been pursued with the object of him becoming a portion of the labouring population and forming an integral part of it and it was this which had caused all such attempts to end in failure:

The two races can never amalgamate, the white labourer, and the native (be he ever so useful) can not be brought to work together on equal terms. We could never succeed in incorporating the native with the mass of the labouring population for there is always enough of that antipathy of races existing, to induce the settler to place the native, however deserving, in an inferior position to his white servants, and to give him the more menial offices to perform; but if the settler being a friend of the aboriginal cause, were not disposed to make any distinction but that of merit, the servants themselves would not perform those offices, whilst they could shift it on to that of the blacks; therefore if the native were to accept the terms of civilization that we offer him, everything would conduce to keep him in the lowest scale of society; he would be constantly subject to all sorts of oppression, and would make but a bad exchange for his native independence. ${ }^{47}$ While officials, missionaries and landowners sought to encourage the Aborigines to become 'ordinary labourers for wages' they wanted to keep them away from the influence of irreverent, assertive colonial workers. The blacks were to become servants but in doing so should behave according to an idealised pattern of deference and loyalty rather than take their cue from the actual workforce. A magistrate in Victoria's Western District observed that in their contact with the white man the blacks had 'acquired all the vices of the labouring population with whom they have so much mixed'. ${ }^{48}$ James Gunther thought that the white workers 'either make too familiar'

43 Select Committee on the Native Police, QV \& P, 1861/26.

44 Thorne, 1876:308.

45 Annual Report, 1848, Papers of the Port Phillip Protectorate, VPRO, Box 11.

46 Curr, 1883:299.

47 The Examiner, 3 December 1842.

48 Pilleau, NSWLCV \& P 1849/22. 
with the blacks teaching them 'all their tricks and vices' or they 'abuse and vex them' ${ }^{49}$ G.A. Robinson, Chief Protector in the Port Phillip district, was so concerned with the situation that he felt unable to recommend that Aborigines should work for the settlers because of the character of the rural workforce. He wrote that:

the difficulty on the part of the Aborigines by proper management can be overcome; but the difficulty on the part of the depraved white man is of far different character ... their place should be supplied by a more honest and industrious peasantry. 50

The solution was to try and keep black servants away from their white counterparts. The Tasmanian settler J.H. Wedge explained that he did not allow his servant Mayday 'to live or associate with servants but had him to live with me in my tent'.51 While thinking about the problems of assimilation, Sir Thomas Mitchell toyed with the idea of sending a young black couple to southern Europe where they could learn how to cultivate Mediterranean crops. After ten years they could be repatriated when, speaking a foreign language, they 'would be less open to the influences that interpose between employees and employed' in New South Wales. ${ }^{52}$ Regulations drawn up for the Victorian Native Police indicated that the troopers were to be taught to discriminate between 'the different classes of white people showing respect to the upper and well conducted' while avoiding those who would 'instruct them in vicious or disorderly habits'.53 A rural magistrate advocated schools for Aboriginal children in order to 'alter in many instances the original bent of the mind'; but it would be essential to 'remove them from licentious intercourse with the labouring population till their principles were in a measure formed'.54

Institutionalisation appeared to be the most effective means to separate the blacks from the white working class as well as serving other purposes. This was proposed as early as 1819 . While discussing plans for an Aboriginal institution the Reverend Robert Cartwright explained that his object was:

to keep these black Natives entirely separate from our own people till the Institution is become sufficiently strong, and the work of civilization so far advanced as to be proof against the evil practices and examples of our countrymen. The only security for their gradual and real improvement .... is to keep them as much and as long separate as possible from the bad example of those around them. ${ }^{55}$

Plans foreshadowed by Cartwright were realised in places like Wybalena, Poonindie and New Norcia. At Poonindie Matthew Hale gathered the blacks in 'one little community apart from the vicious portion of the white population'.56 Salvado moved his mission to New Norcia at the first appearance of white shepherds 'so as to keep

49 Gunther, 23 April 1838, ML MSS B504.

50 Robinson to La Trobe, 30 August 1841, Aborigines: Australian Colonies, BPP 34/627/1844/132.

51 Bonwick, 1870:356.

52 Mitchell, 1848:416.

53 Aborigines and the Native Police, 1835-44, NSWCSO 4/1135.1.

54 Select Committee on the Aborigines and the Protectorate, NSWLCV \& P 1849/37.

55 Cartwright to Macquarie, 6 December 1819, BPP 19/261/1831.

56 Hale, 1889:10. 
the natives out of contact with corrupting influences'.57 At Wybalena Robinson was able for a short time to believe that he had created an orderly and hierarchical society. He wrote to the Tasmanian Colonial Secretary in 1836 describing the celebration of the Sabbath:

At sunrise the Union Jack is hoisted at Mt. Arthur and hauled down again at sunset. The hoisting of the flag is the signal for the Aborigines to prepare for Church after which they wait about their huts in clean and neat attire until the tolling of the Bell when they join me in company and in an orderly and becoming manner proceed with me to the Church. Their conduct during divine worship is of the most exemplary kind. They are quiet and attentive to what is said . . . the Greatest possible respect is paid to the Sabbath, there is no strolling about, the religious services are well attended and all amusements are refrained from..$^{58}$

While colonial Australia was characterised by a hierarchical, unequal society with sharp gradations of status, the race question was, of necessity, also a 'class' question. Policy makers saw assimilation very specifically in terms of absorption in the lower orders. 'Civilisation' itself implied the inculcation of those habits of order, obedience and industry which were thought appropriate for servants and hired labourers. But the elite did not want the blacks to be assimilated into the actual working class. Rather they wished them to conform to an upper class vision of how the lower orders ideally should behave; and on reserves and missions the implementation of that vision was often carried to bizarre lengths. Aboriginal policy failed to resolve the deep contradiction of both wanting and not wanting the Aborigines to merge with the 'lower ranks of mechanics'.

For their part the Aborigines may have resisted whatever white society proposed for them. But in the circumstances their rejection of 'civilisation' was the rejection of the life of the poor and powerless. They resisted the demands of wage labour, the submissive role of the servant and the restraints which were imposed on ordinary labourers'. They quickly realised that what the whites were offering was for them to become, as George Grey put it, "ever a servant - ever an inferior being' ${ }^{59}$ That realisation continued to shape Aboriginal behaviour throughout the second half of the nineteenth century and beyond.

57 Stormon, 1977:71.

58 Robinson to Montagu, July 1836, ML MSS A7044/23.

59 Grey, 1841(II):370-1.

\section{BIBLIOGRAPHY}

Aborigines: Australian Colonies. British Parliamentary Papers (BPP). BPP 34/627/1844.

Aborigines and the Native Police, 1835-1844. New South Wales Colonial Secretary (NSWCSO).

In Letters, Special Bundles NSWCSO 4/1135.1.

Bonwick, J. Transcripts. Mitchell Library (ML).

.The Last of the Tasmanians. London, 1870.

Bulmer, J. 'Some Account of the Aborigines of the Lower Murray, Wimmera and Maneroo', in

Proceedings of the Royal Geographical Society of Victoria. Part 1, vol. 5, March 1888.

Curr, Edward. Recollections of Squatting in Victoria. Melbourne, 1883. 


\section{ABORIGINES AND EUROPEAN SOCIAL HIERARCHY}

Dawson, Robert. The Present State of Australia. London, 1830.

Dixon, John. The Condition and Capabilities of Van Diemen's Land. London, 1839.

The Examiner (Adelaide).

Grey, George. Journals of Two Expeditions of Discovery. 2 vols. London, 1841.

Gunther, James. Journal. ML MSS B504.

Lectures on the Aborigines. ML MSS B505.

Hale, Matthew. The Aborigines of Australia. London, 1889.

Historical Records of Australia (HRA).

McBryde, Isabel. ed. Records of Times Past. Canberra, 1975.

Mitchell, Thomas. Journal of an Expedition into the Interior of Tropical Australia. London, 1848. Three Expeditions into Eastern Australia. 2 vols. London, 1834.

New South Wales. Return to an Address . . f for copies of Instructions Given to His Majesty's Secretary of State for the Colonies, for Promoting the Moral and Religious Instruction of the Aboriginal Inhabitants of New Holland and Van Diemens Land. BPP 19/261/1831.

New South Wales (Aborigines). Return to an Address by Dr Thomson . . . comprising Details of Government Expenditure on Aborigines 1837-1843. New South Wales Legislative Council Votes and Proceedings (NSWLCV \& P), NSWLCV \& P 1843.

New South Wales and Victorian Miscellaneous Papers 1817-1873. ML MSS A1493.

Orton, Joseph. Journal. ML MSS A1715.

Papers of the Port Phillip Protectorate. Victorian Public Records Office (VPRO).

Report from the Select Committee on the Aborigines. BPP 7/538/1837.

Robinson, G.A. Letterbook. ML MSS A7044.

Rusden, G.W. History of Australia. 3 vols. London, 1883.

Select Committee on the Aborigines. NSWLCV \& P 1845.

Select Committee on the Aborigines and the Protectorate. NSWLCV \& P 1849.

Select Committee on the Native Police. Queensland Votes and Proceedings (QV \& P), 1861.

Stormon, E.J. ed. The Salvado Memoirs. Perth, 1977.

Thomas, William. Letterbook and Journal, ML MSS 214/8.

Thorne, Ebenezer. The Queen of the Colonies. By 'An Eight Years Resident'. London, 1876.

West Australian Colonial Secretary. In Letters (WACSO).

Woolmington, J.ed. Aborigines in Colonial Society. Melbourne, 1973. 